\title{
Interest Dispute Settlement Related to Workers' Health Care Security in Indonesia
}

\author{
Dewa Nyoman Rai Asmara Putra* \\ Faculty of Law, Udayana University, Bali, Indonesia \\ Kadek Agus Sudiarawan ${ }^{* *}$ \\ Faculty of Law, Udayana University, Bali, Indonesia \\ Ari Mahartha ${ }^{* * *}$ \\ RAH (The House of Legal Experts) Law Office, Bali, Indonesia
}

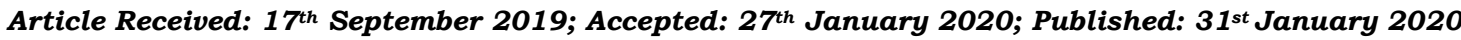

\begin{abstract}
The enactment of Law Number 24 of 2011 concerning the Social Security Organizing Body (BPJS Law) has legal implications especially for employers and workers before the enactment of the BPJS Law, the Parties had already agreed that Private Health Insurance as an organizer of workers' health insurance on Collective Labor Agreement (CLA). This condition provides a possibility for the emergence of conflicts of interest. The problem raised in this legal research is how is the regulation concerning the employers' obligations in the health insurance of workers after the enactment of the BPJS Law; what are the legal implications if the CLA in the company before the enactment of BPJS Law has implemented the scheme of Health Insurance for Workers through Private Insurance; and how the legal steps that can be taken in resolving disputes arising related to this matter. This study uses normative legal research methods with a statute approach and a case approach. The result of this research shows that after the enactment of BPJS law, the Employer is obliged to register all of the Workers to BPJS membership as the national provider of health care security system. In terms of double coverage of Workers' health insurance which impacted the company, the parties could negotiate to amend the CLA based on mutual agreement and good faith. In terms of an interest dispute in implementing the CLA about workers' health insurance is happening in the future, legal actions that can be taken accordance with the provisions of the Industrial Relations Disputes Settlement Law are bipartite, tripartite disputes settlement through mediation, conciliation, arbitration, and submit a lawsuit to Industrial Relations Court
\end{abstract}

Keywords: Collective Labor Agreement; Health Care Security; BPJS Law

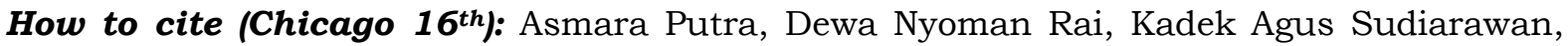
and Ari Mahartha. "Interest Dispute Settlement Related to Workers' Health Care Security in Indonesia." Udayana Journal of Law and Culture 4, no. 1 (2020): 62-80. https://doi.org/https://doi.org/10.24843/UJLC.2020.v04.i01.p04.

doi: https://doi.org/10.24843/UJLC.2020.v04.i01.p04

\footnotetext{
* Email corresponding author: dewar2566@gmail.com

** Email : agus_sudiarawan@unud.ac.id

${ }^{* * *}$ Email: ari.mahartha@gmail.com
} 


\section{Introduction}

Kadek Agus Sudiarawan and Ari Mahartha

\subsection{Background}

Social security is the right of every citizen as mandated in the 1945 Constitution of the Republic of Indonesia (the Constitution of Indonesian). ${ }^{1}$ This constitutional mandate was then further regulated into the Law Number 40 Year 2004 concerning the National Social Security System ("NSSSLaw"). The NSSS Law has a philosophical foundation that every person has the right to social security to be able to fulfill the basic needs of a decent life and increase dignity towards the creation of a safe, just and prosperous Indonesian society. ${ }^{2}$ Social security which is the target area of the NSSS Law includes health insurance, work accident insurance, old-age pension, public pension, and life insurance. In the enactment of the NSSS Law, the social security programs are carried out by several bodies that implement each of the social security programs, including a. Limited Liability Company (Persero) Workers' Social Security / JAMSOSTEK; b. Limited Liability Company (Persero) Savings Fund and Civil Servant Insurance / TASPEN; c. Limited Liability Company (Persero) Armed Forces / ASABRI Social Insurance; and D. Limited Liability Company Indonesian Health Insurance (ASKES).

In some periods of time the implementation of social security by using the institutional pattern as stated in the National Social Security Law, it is necessary to amend the implementation of the national social security program which aims to provide certainty of protection and social welfare for all people. ${ }^{3}$ Therefore, an organizing body in the form of a legal entity was formed based on the principles of mutual cooperation, non-profit, openness, prudence, accountability, portability, mandatory participation, mandate funds, and the results of the management of social security funds in full for program development and for the maximum extent possible the interests of the participants. The intended legal entity is the Implementing Agency of Social Security established under Law Number 24 Year 2011 concerning the Social Security Organizing Body (Badan Penyelenggaraan Jaminan Sosial or "BPJS Law"). With the enactment of the BPJS Law, there are fundamental things that have amende in terms of the implementation of the national social security program that has implications for various existing stakeholders. One of the most fundamental and impactful changes is the "mandatory" nature of participation in social security programs for the entire population. In this paper, the subject of discussion is the social

1 Jimly Asshiddiqie. Komentar atas Undang-undang Dasar Negara Republik Indonesia Tahun 1945, Cetakan Pertama (Jakarta: Sinar Grafika, 2010), 135.

${ }^{2}$ See the considering section of the Act No. 40 Year 2004 concerning the National Social Security System.

3 Tonia Warnecke \& Alex De Ruyter. "The Enforcement of Decent Work in India and Indonesia: Developing Sustainable Institutions." Journal of Economic Issues 46, no. 2 (2012): 397-398. 
security program in terms of health, which after the enactment of the BPJS Law, based on Article 6 paragraph (1), the health security program is carried out by a legal entity called BPJS for Health with a health security program named National Health Insurance (JKN).

The amendment in the national health security pattern from what was originally held by PT Askes (Persero) ${ }^{4}$ based on the National Social Security System Law which later transformed into the BPJS for Health based on the BPJS Law has implications for business actors which in the context of employment law are referred to as Employers in terms of ensuring the health of their Workers. This implication arises because there is a significant addition related to the national health insurance program in which after the enactment of the BPJS Law, the Employer is "obliged" to register himself and all of his Workers into BPJS for Health membership. This has become so felt the impact for the Employer considering that prior to the enactment of the BPJS Law, the Employer is free to determine the health insurance program used to guarantee the health services of his Workers. The Health Insurance Program which is organized in collaboration with a Private Insurance Company is one of the choices that is chosen by many employers to ensure the health of their employees before the enactment of the BPJS Law. Workers are also familiar with the use of health insurance by Private Insurance with various facilities and facilities offered by Private Health Insurance Providers. Legal issues that then occur with regard to these conditions, namely the existence of an Acting Employer to shift the health insurance program for Workers from those who originally used Private Insurance to a national health insurance program organized by BPJS for Health. The transfer of the health insurance program does not necessarily lead to an easy path for the Employer, due to the possibility of rejection from Workers who have previously enjoyed the facilities provided by Private Health Insurance and there is fear that the transfer of the health insurance program to BPJS for Health will obtain facilities and decreased pleasure. This refusal from the Workers becomes one of the important issues for the Employer whose health insurance program using Private Insurance has been regulated and agreed to in a binding autonomous law for the Parties, the Collective Labor Agreement (CLA). In this case, the Employer seems to have no other choice but to continue to implement the contents of the Collective Labor Agreement by imposing a health insurance program with Private Insurance and carrying out the BPJS Law orders to register his Workers as BPJS for Health participants. Such conditions certainly have an impact on the Employer, who must bear health insurance coverage for his Workers in a double (double coverage).

${ }^{4}$ Tania Murray Li "The Price of Un/Freedom: Indonesia's Colonial and Contemporary Plantation Labor Regimes." Comparative Studies in Society and History 59, no. 2 (2017): 259-260. 


\subsection{Research Problem}

Kadek Agus Sudiarawan and Ari Mahartha

Based on the problem has been mentioned above then become the basis for the author as well as the background of this Legal Research. Based on this background, as for some of the issues that will be discussed in this Legal Research are: 1) What is the arrangement of the Company's obligations in workers' health coverage after the enactment of the BPJS Law? 2) What are the legal implications that arise if the Collective Labor Agreement of the Company before the Applicable BPJS Law has implemented the Worker Health Coverage scheme through Private Insurance?; and 3) What is the legal steps that can be taken in resolving disputes arising in connection with workers' health coverage at a company after the enactment of the BPJS Law? The purpose of this legal research is to identify the Company's liability arrangements for workers' health coverage after the enactment of the BPJS Law; identify the legal implications that arise if the Collective Labor Agreement before the Law BPJS Applicable has implemented the Worker Health Coverage scheme through Private Insurance; as well as knowing the legal steps that can be taken in resolving disputes arising related to workers' health coverage at a company after the enactment of the BPJS Law.

\subsection{Research Methods}

In this paper, the research method used is normative legal research. Normative legal research is research conducted through the study on laws and regulations ${ }^{5}$ that apply to a particular legal problem. ${ }^{6}$ In normative legal research, the object of study is legislation using a statute approach and case approach based on industrial relations cases that occur as implications of the existence of new regulations regarding obligations The Employer to register all his Workers in the membership of the National Health Insurance organized by BPJS for Health.

\subsection{Theoretical Framework/Literature Review}

Article 7 paragraph (1) Law Number 13 Year 2003 concerning Manpower ("Labor Law") stipulates that the role of the government in terms of industrial relations is to establish policies and arrange workforce planning in the context of labor development. The government in formulating policies, strategies and implementing employment development programs is based on workforce planning. The manifestation of the role of the government, in this case, is nothing but stipulated into legal products

5 Depri Liber Sonata, "Metode Penelitian Hukum Normatif dan Empiris: Karakteristik Khas dari Metode Meneliti Hukum." Fiat Justisia Jurnal Imu Hukum 8, no. 1 (2014): 24-25.

${ }^{6}$ Karen Petroski, "Legal Fictions and the Limits of Legal Language." International Journal of Law in Context 9, no. 4 (2013): 488. 
that have the nature of regulating employment relations between workers and employers who are present as a counterweight. In the context of industrial relations, Workers and Employers can form a separate agreement between them which acts as a binding law between them. The provisions stipulated in the agreements made and agreed by the Parties are referred to as autonomous law. Autonomous law is legal provisions in the field of employment made by the parties involved in an employment relationship, both between the employer and the worker and between the employer and the worker union. ${ }^{7}$ However, the rules of employment law made by third parties who are outside the parties bound in the employment relationship are named heteronomous law. 8

In this research, the autonomous law that will be used as the main focus in the discussion is autonomous law in a company created and agreed upon by the Employer with a Worker Union, namely the Collective Labor Agreement ("CLA"). Article 1 number 21 of the Labor Law defines Collective Labor Agreement as an agreement resulting from negotiation between a worker/labor union or several worker/labor unions registered at the institution in charge of the manpower affairs and entrepreneurs or group of entrepreneurs, which contains working requirements, rights and obligations of parties. With the provisions made and agreed by the Employer with the Worker Union as outlined in the CLA, automatically there are other rights and obligations that must be fulfilled by the parties besides implementing the provisions of the legislation. This situation has implications for the employment relationship between the parties where there are possibilities that what is regulated in the autonomous law has a different arrangement than what is regulated in the legislation on the same object for example in terms of health care security coverage by the Employer to the worker. In this case, the issue of differences in regulations regarding health insurance coverage in the CLA and the Legislations will be sensitive considering the different interests of the parties in viewing health care security coverage which then has the potential to lead to interest disputes.

\section{Result and Discussion/Analysis}

\subsection{Regulation of Company Obligations in Workers' Health Care Security Coverage After the Enactment of BPJS Law}

Social Security is the right of every person guaranteed by the NSSS Law. Social Security in question is a guarantee to be able to meet the basic needs of a decent life and increase its dignity towards the realization of a prosperous, just and prosperous Indonesian society. This is as aspired in

${ }^{7}$ Susilo Andi Darma, "Kedudukan Hubungan Kerja; Berdasarkan Sudut Pandang Ilmu Kaidah Hukum Ketenagakerjaan dan Sifat Hukum Publik dan Privat." Mimbar HukumFakultas Hukum Universitas Gadjah Mada 29, no. 2 (2017): 223.

${ }^{8}$ Ibid 
the formation of the NSSSLaw which is included in the $1^{\text {st }}$ point of the considering section. Social security is designed to provide significant benefit to the community as social security participants by ensuring the fulfillment of basic needs that are appropriate for the participant along with family members, which includes comprehensive health services. ${ }^{9}$

One of the strategic steps taken by the State in realizing this is through the establishment of the Social Security Organizing Agency as mandated in Article 5 paragraph (1) of the National Social Security Act which was previously implemented by the establishment of several Social Security Organizing Bodies, namely:

a. PT (Persero) Workers' Social Security / JAMSOSTEK;

b. PT (Persero) Savings Fund and Civil Servant Insurance / TASPEN;

c. PT (Persero) Armed Forces / ASABRI Social Insurance; and

d. PT Indonesian Health Insurance (ASKES).

Whereas then based on the enactment of the Law of the Republic of Indonesia Number 24 of 2011 concerning the Social Security Organizing Agency (hereinafter referred to as the "BPJS Law"), it is deemed necessary to carry out a transformation of the four State-Owned Enterprises into a National Social Security Administering Board to accelerate the implementation of the system national social security for all Indonesian people. 10 Whereas based on these considerations, a legal entity was established to carry out a national social security program, namely the Social Security Organizing Agency (BPJS) which includes the Health BPJS and the Employment BPJS. The Health BPJS based on Article 6 paragraph (1) of the BPJS Law organizes a health insurance program, while the BPJS Employment based on Article 6 paragraph (2) of the BPJS Law organizes a work accident insurance program, old-age insurance, pension insurance, and death insurance.

With the enactment of the BPJS Law and the commencement of the operation of the Health BPJS as the organizer of the health insurance program on January 1, 2014, there will be implications for the 2 (two) previous social security organizing bodies, including:

1. PT. Jamsostek (Persero) was declared dissolved without liquidation and all assets and liabilities as well as legal rights and obligations, were transferred to BPJS Employment and no longer held a health care insurance program;

9 Andri Putra Kesmawan and Dyah Mutiarin, "Implementasi Kebijakan Badan Penyelenggara Jaminan Sosial (BPJS) Kesehatan di Kabupaten Bantul Daerah Istimewa Yogyakarta." Journal of Governance and Public Policy 1, no. 3 (2016): 507.

${ }^{10}$ Surabhi Chopra, "Legislating Safety Nets: Comparing Recent Social Protection Laws in Asia." Indiana Journal of Global Legal Studies 22, no. 2 (2015): 583584. 
2. PT. Askes (Persero) was declared dissolved without liquidation and all assets and liabilities as well as legal rights and obligations transferred to BPJS for Health.

The changing form of PT Askes (Persero) brought changes in several fields, including the Social Security Organizing Agency which no longer took the form of a State-Owned Enterprise, but instead became a Public Legal Entity that has direct accountability to the President. The implementation of the National Health Insurance program by the Health BPJS uses the principle of social insurance which has a different character from SOEs pursuing profits. ${ }^{11}$ BPJS for Health has an orientation to service to the community by managing as well as possible the funds which are mandates collected from participant contributions for the welfare of all participants. ${ }^{12}$ In addition, social security coverage is compulsory and broader such as the mandatory BPJS for Health for the entire population as well as the BPJS Employment required for all workers. ${ }^{13}$ The obligation to administer the National Health Insurance has been regulated in the BPJS Law, namely, in Article 4 letter $g$ it is stated: "BPJS organizes a national social security system based on the principle of membership being mandatory". In the elucidation of Article 4 letter $g$, it is stated that what is meant by "the principle of membership is compulsory" is the principle that requires all residents to become Social Security Participants, which is carried out in stages. In the context of Manpower, Article 14 of the BPJS Law stipulates that "Every person, including foreigners who work for a minimum of 6 (six) months in Indonesia must be a participant in the Social Security program", in which case, the Social Security program membership of workers is facilitated by registration. Employer. This is regulated in Article 15 paragraph (1) of the BPJS Law, which states that "Employers must gradually register themselves and their Workers as Participants to BPJS in accordance with the Social Security program that is followed." Then those required to be registered with the BPJS program by the Employer also include family members. These provisions than have an impact on the Company, including:

a) The company is required to register its employees with BPJS for Health

b) The company shall allocate additional funds to pay contributions to the BPJS for Health

11 Widya Hartati, "Kajian Yuridis Perubahan PT. Askes (PERSERO) Menjadi Badan Penyelenggara Jaminan Sosial (BPJS) Kesehatan.” Jurnal IUS Kajian Hukum dan Keadilan 3, no. 3 (2015): 494.

12 Ibid.

${ }^{13}$ Shihab, A. N. "Hadirnya Negara Di Tengah Rakyatnya Pasca Lahirnya UndangUndang Nomor 24 Tahun 2011 Tentang Badan Penyelenggara Jaminan Sosial (The Presence Of The State Among People After The Declaration of Law Number 24 Year 2011 Concerning Social Security Administering Agency)." Jurnal Legislasi Indonesia 9, no. 2 (2018): 186. 
The Requirement of an Employer in registering all Workers to BPJS membership is followed by the application of sanctions for the Employer if they do not implement the provisions, namely administrative sanctions as regulated in Article 17 paragraph (1) of the BPJS Law which can be in the form of a. a written warning; b. fine; and/or c. do not get certain public services. In addition to the obligation of the Employer to register his Workers in BPJS membership, the Employer is also given an obligation by the BPJS Law in terms of collecting contributions which are borne by participants from their Workers and depositing them to BPJS, as well as being obliged to pay and deposit contributions which are their responsibility to BPJS. Both obligations of the Employer are regulated in Article 19 paragraph (1) and paragraph (2), and for violations of these provisions by the Employer, the BPJS Law stipulates sanctions in the form of imprisonment for a maximum of 8 (eight) years or a maximum fine of $\mathrm{Rp} 1,000,000,000.00$ (one billion rupiahs).

\subsection{Legal Implications Arising if the Collective Labor Agreement of the Company before the Enactment of BPJS Law has Implemented Workers' Health Care Security Coverage Scheme through Private Medical Insurance}

The enactment of the BPJS Law which requires employers to register all workers in the National Health Insurance membership held by the Health BPJS has practical implications in industrial relations between the Employer and Workers. The practical implications are then felt especially by the Employer who prior to the enactment of the BPJS Law has provided health insurance facilities to Workers in collaboration with Private Insurance as the organizer. With the enactment of the BPJS Law which requires the Employer to register workers with JKN membership, a double coverage will occur for the health insurance of all workers. Especially if the health insurance coverage that uses the facilities of the Private Insurance has been poured into a Collective Labor Agreement, which has become a binding legal rule between the Employer Party and the Worker, in this case the Labor Union and must continue to be carried out by the Parties although with the enactment of the new national provisions concerning health insurance that is the BPJS Law. This then naturally becomes a burdensome matter for the Employer Parties where they must cover the Worker's health insurance in a double manner even though in practice the Worker does not use all of these facilities but due to the National Health Insurance coverage system which is cross-subsidized to other participants, the Employer must remain to pay National Health Insurance contributions in each payment period. In fact, in some cases National Health Insurance participants, in this case, Workers prefer to use health facilities provided from participation in Private Health Insurance because they are accustomed 
to and consider services provided in the National Health Insurance as not satisfactory enough. Thabrany in Kesmawan \& Mutiarin stated that "participants with top-level economic class are not satisfy with JKN services". ${ }^{14}$ Then BPJS for Health services also complained a lot and became a problem in the community where a lot of the reports that entered the Ombudsman Republic of Indonesia (ORI) which were quite high in 2015 related to the administration of bureaucracy, registration, up to the long queues and related to payments. ${ }^{15}$ Another problem that occurred is the demonstrate that occurred in Bandung by workers who are members of the Indonesian Workers Union (IWU) in front of the BPJS for Health Office Pasteur asking for a delay in participation as BPJS for Health participants due to workers objecting to the coercion of them to become BPJS for Health participants by Employer. ${ }^{16}$

The conditions as previously stated become the implications of the enactment of the BPJS Law specifically in terms of the obligation of the Employer to register all of his Workers in JKN membership where there is a conflict of interest between the Parties in industrial relations. This is especially true for companies that have implemented health insurance coverage with Private Insurance before the enactment of the BPJS Law. In terms of the Employer, the Employer is obliged to guarantee the health of his Workers, which has been done previously in collaboration with Private Insurance as the organizer, but on the other hand, the Employer is also obliged to carry out the Act which requires the Employer to use the National Health Insurance Health BPJS. While from the side of Workers who are accustomed to enjoying qualified health insurance facilities from Private Health Insurance, refuse to transfer these facilities to the National Health Insurance from BPJS for Health because it is considered that the facilities provided in health services by BPJS for Health are no better than health facilities from Private Health Insurance which has been enjoyed by workers. Where the conflict of interest between the Parties may then become a difference of understanding between the Parties which cannot find a solution between the Parties until it leads to a Dispute of Interest which must be settled in accordance with the stages of the Industrial Relations Dispute Settlement as regulated in the Law Number 2 of 2004 concerning Settlement of Industrial Relations Disputes.

${ }^{14}$ Andri Putra Kesmawan and Dyah Mutiarin, op. cit., 508

15 Arip Suprianto and Dyah Mutiarin.. "Evaluasi Pelaksanaan Jaminan Kesehatan Nasional." Journal of Governance and Public Policy 4, no. 1 (2017): 73

${ }^{16}$ Veny Afrilia, Suwandi Sumartias, and Lukiati Komala Erdinaya Transformasi PT Askes (PERSERO) Menjadi Badan Penyelenggara Jaminan Sosial Kesehatan." Jurnal Kajian Komunikasi 5, no. 2 (2017): 182. 


\subsubsection{Review of Workers' Health Care Security Coverage Reduction Through Private Insurance By Referring to Company Obligations in BPJS Law}

The shift in the implementation of the National Social Security System, especially in terms of health insurance with the enactment of the Law on BPJS, has an impact on the health insurance of Workers, which becomes an obligation for the Employer to register Workers in BPJS for Health membership. From a Workers' perspective, this is seen as a loss where the rights in the form of health facilities that have been obtained from the implementation of health insurance by Private Insurance which is very qualified for them are "reduced" by the mandatory membership of BPJS for Health. ${ }^{17}$ Workers and employers are then confronted with situations of conflicting interests. This conflict of interest is caused by the presence of the Employer Party with the obligation to apply for health insurance with BPJS for Health to all workers. This is an order of the Law where there is a threat of sanctions imposed on the Employer if they do not carry out the registration of Workers to BPJS for Health membership. This is in accordance with the provisions of Article 5 of the Government Regulation of the Republic of Indonesia Number 86 the Year 2013 concerning Procedures for Imposing Administrative Sanctions to Employers Other Than State Administrators and Everyone, Other Than Employers, Workers, and Recipients of Contribution Aid in Providing Social Security. In this provision, there are administrative sanctions for employers that can be in the form of written warnings, fines, and/or not receiving certain public services, to sanctions that lead to business-related licensing. So that if this provision is violated it will lead to greater consequences for the sustainability of the company which has the potential to be closed so that it also impacts the potential loss of work for workers.

Whereas if referring to the ideals to be achieved in the framework of the implementation of the National Health Insurance in the BPJS Law it has been very ideal and should be able to accommodate the needs of the whole community in particular Workers in a Company. This is as stated in the considerations of the BPJS Law, namely the national social security system is a program that aims to provide certainty of protection and social welfare for all people. This has also been strengthened by Decision of the Constitutional Court Number 7 / PUU-XVII / 2019, dated February 11, 2019, concerning the Judicial Review Case against Article 14 of Law Number

${ }^{17}$ Budi Setiyono \& Ian Chalmers "Labour Protection Policy in a Third World Economy: The Case of Indonesia." Development and Society 47, no. 1 (2018): 142-143. 
24 of 2011 concerning the Social Security Organizing Body. ${ }^{18}$ In the judicial review case, the Petitioner argued that Article 14 of the BPJS Law which states "every person including foreigners who work for a minimum of 6 (six) months in Indonesia, must be a Participant in the Social Security program" is against the Constitution, which is then rejected by the Constitutional Court by citing legal considerations of other Constitutional Court cases in MK Decision Number 138/PUU-XII/2014, dated December 7, $2015^{19}$ which states as follows:

"That social insurance as a social security system is in line with the values of the Pancasila and the mandate of the 1945 Constitution because it will create social justice by fostering an awareness of individual obligations towards the public collectively as an embodiment of cultural life that prioritizes common interests"

"According to the Court, the word" state "in Article 34 paragraph (2) of the 1945 Constitution also includes the participation of the government, regional government and private parties to participate in developing a social security system by providing health facilities for the community, especially in the corners of regions of the homeland are still not available health facilities in the area have been submitted to their respective local governments, so that in the future both the local government and private parties will build adequate facilities and BPJS will pay anyone seeking treatment at the health facility, or in the form of insurance additions that will meet health needs and services that exceed the basic needs they deserve."

Through this Decision, the Constitutional Court is of the opinion that Article 14 of the BPJS Law which states "everyone including foreigners who work for a minimum of 6 (six) months in Indonesia, must be a participant in the Social Security program", does not contradict the constitution with the consideration that the Constitutional Court emphasizes the interests of the wider community in which in this case the private sector is one of the partners included in the definition of "state" in Article 34 paragraph (2) which is obliged to realize social security for all Indonesian people in accordance with the spirit of the constitution.

The purpose of the establishment of the BPJS Law is actually very ideal in guaranteeing the protection and social welfare of all people, but this very noble goal should be accompanied by a professional organization so as not to cause negative perceptions among the public users of national health

${ }^{18}$ See Constitutional Court Decision Number 7/PUU-XVII/2019, dated February 11, 2019 concerning Judicial Review Case Against Article 14 of Law Number 24 Year 2011 concerning Social Security Organizing Body.

19 See Constitutional Court Decision Number 138/PUU-XII/2014, dated December 7, 2015. 
insurance services, so it is not considered a reduction benefits for Workers who previously enjoyed health insurance facilities provided by Private Health Insurance.

\subsubsection{Review of Workers' Refusal to Reduction in Benefits or Facilities for Workers' Health Care Security which Previously Using Private Medical Insurance Switching to BPJS for Health}

Amendment in health insurance arrangements that are nationally Employers are required to register their Workers in the membership of the Health BPJS implications for the engagement relationship that has occurred between the Parties who before the enactment of the BPJS Law had imposed a Collective Labor Agreement (CLA) as an autonomous law in industrial relations in between the Employer and the Workers Union. ${ }^{20}$ The main issue, in this case, is whether the Workers can reject the effectiveness of BPJS for Health membership where CLA previously stated that workers' health insurance is carried out with Private Health Insurance. In answering this issue, it is important to remember that the position of the BPJS Law is a public law that is forced (dwingendRecht) and there are sanctions if the provisions are not implemented. Then the CLA is made based on an agreement by the Parties in accordance with Article 1338 paragraph (1) of the Civil Code which is a supplementary law (aanvullend Recht). This is as stated by Subekti that the regulations contained in Book III of the Civil Code are generally a supplementary law (aanvullendRecht) and not compulsive (dwingendRecht). ${ }^{21}$ In terms of nature, the structure of the rule of law can be distinguished from imperative law (legal force / dwingend Recht) and facultative law (governing law of complementary law / regelend Recht or aanvullendRecht). The distinction of the nature of this law is emphasized on the strength of the sanctions, where the law is forced, namely in a concrete situation that cannot be ruled out by agreements made by the parties themselves, so that under any circumstances the law must be obeyed absolutely / absolutely. Whereas the law regulates that in concrete circumstances can be ruled out by agreements made by the parties. ${ }^{22}$

Thus the enactment of the BPJS Law as a public and compulsory law can override CLA's position as a compliment, but limited to the provisions governing health insurance for Workers. Then when referring to the provisions of Article 1338 paragraph (2) of the Civil Code, it is expressly

${ }^{20}$ Ruben L. Situmorang, "Tinjauan Yuridis Tentang Perjanjian Kerja Bersama Ditinjau Dari Undang-Undang Nomor 13 Tahun 2003 Tentang Ketenagakerjaan." Lex Privatum 1, no. 1 (2013): 118. 127.

${ }^{21}$ R. Subekti, Hukum Perjanjian.Cetakan ke-22." (Jakarta: PT Intermasa, 2008),

${ }^{22}$ Muhammad Djumhana, Hukum Perbankan di Indonesia. (Bandung: PT Citra Aditya Bakti, 2010), 9. 
stated that "the Agreement cannot be withdrawn other than by agreement of both parties, or for reasons determined by law." What is meant by "reason which is determined by the law "in this case is a statutory provision that is compelling (dwingend Recht), so that in this context the BPJS Law can be qualified as a law which is the basis for the amendment to the provisions in the CLA relating to the implementation of workers' health insurance.

The Collective Labor Agreement can be amended with the good faith of the Parties. ${ }^{23}$ In accordance with the Goodwill Principles known in treaty law in Indonesia, it is regulated in Article 1338 paragraph (3) of the Civil Code, namely that in the formulation it is stated that "Agreement must be carried out in good faith". Good faith, in this case, is based on moral values and conscience. In implementing the contract, Good Faith is a legal institution (rechtsfiguur) derived from Roman law which was then absorbed by Civil Law. ${ }^{24}$ Good faith is divided into 2 (two) types, namely good faith relative and absolute good faith. As for what is considered in Nisbi Good Intentions is the real attitudes and behavior of the subject of the Agreement, then what is considered in the Absolute Good Intentions is assessed on common sense and justice by making objective measures in assessing a situation according to objective norms (judgments made not taking sides, ${ }^{25}$ Wirjono Prodjodikoro provides a limitation of good faith using the terms "honest" or "honestly"26Wirjono Prodjodikoro also divides good faith into 2 (two) types, namely:27

1. Good faith at the time a legal relationship is effective. In this case, good faith is usually in the form of an estimate or a person's assumption that the conditions needed for the commencement of a legal relationship have been fulfilled; and

2. Good faith at the time of exercising the rights and obligations stated in the legal relationship. Good faith in this sense is none other than what is stipulated in Article 1338 paragraph (3) of the Civil Code which focuses on actions to be taken by both parties, namely the act of implementing a matter agreed upon by the Parties.

${ }^{23}$ Refly Umbas, "Aspek Hukum dalam Perjanjian Kerja Bersama (PKB) antara Karyawan dengan Perusahaan." Lex Privatum 2, no. 3 (2014): 174-175.

${ }^{24}$ Priyono, E. A. "Peranan Asas Itikad Baik Dalam Kontrak Baku (Upaya Menjaga Keseimbangan bagi Para Pihak)." Diponegoro Private Law Review 1, no. 1 (2017): 14.

25 Wisudawan, I. G. A. "The Good Faith Principle of the Parties in the Credit Agreement as an Effort to Minimize the Non Performing Loans at Koperasi Financial Institutions". Ganeswara 7 no. 2 (2013): 58

${ }^{26}$ Ibid.

${ }^{27}$ Ibid. 


\subsection{Legal Measures that can be Taken in Resolving Disputes Arising as to the Coverage of Workers' Health Care Security in the Company after the Enactment of BPJS Law}

In the event that the change in the implementation of Workers' health insurance which was originally at the CLA has been carried out in collaboration with Private Insurance to be administered by using the National Health Insurance by the Health BPJS, it will certainly bring problems and differences of understanding among the Parties which lead to Industrial Relations Disputes which in this case qualify for a Dispute of Interest. 28

In the context of this problem, the absence of conformity of opinion between Workers and Employers regarding changes in health insurance Workers who originally used Private Insurance to switch to the National Health Insurance BPJS for Health in the CLA can be qualified into a dispute of interest. Conflicts of interest between the Parties in industrial relations can be resolved through the mechanism contained in the Procedure for Settling Industrial Relations as regulated in Chapter II of the PPHI Law, including but not limited to:

1) Settlement through Bipartite

Namely the settlement by deliberation to reach consensus. If later in this stage a settlement agreement is obtained, a Joint Agreement is signed by the Parties. This Joint Agreement then binds and becomes law and must be implemented by the parties. A Joint Agreement must be registered with the Industrial Relations Court at the District Court in the territory of the parties entering into a Joint Agreement. 29

2) Settlement through Mediation

That is carried out by the mediator who is in every office of the agency responsible for manpower in the District / City level which is carried out by conducting research on the case sitting and holding a mediation session. ${ }^{30}$ In the event that an industrial relations dispute resolution agreement is reached in the mediation stage, the Parties make a Joint. ${ }^{31}$ In the event that no agreement is reached, the mediator shall issue a written recommendation within not later than 10 (ten) working days from the first mediation session. Then to the

${ }^{28}$ Charda S Ujang, "Model Penyelesaian Perselisihan Hubungan Industrial dalam UU Ketenagakerjaan setelah Undang-Undang Nomor 2 Tahun 2004 Diundangkan". Wawasan Yuridika 1, no. 1 (2017):12-13.

29 Omon Remen, Endeh Suhartini \& Ani Yumarni, Penyelesaian Perselisihan Hubungan Industrial pada PT. Haengnam Sejahtera Indonesia di Tingkat Mediasi pada Dinas Tenaga Kerja Kabupaten Bogor, Jurnal Hukum De'rechtsstaat 4, no.1 (2018).), 90.

30 Jorawati Simarmata "Urgensi Bantuan Hukum Relawan Pendamping, Pekerja Sosial dan Serikat Buruh setelah Putusan MA No 22 P/HUM/2018." Jurnal Hukum \& Pembangunan 48, no. 4 (2018): 689-690.

${ }^{31}$ Yetniwati, Hartati, dan Meriyarni, "Reformasi Hukum Penyelesaian Perselisihan Hubungan Industrial Secara Mediasi." Jurnal Dinamika Hukum 14, no. 2 (2014): 253-254. 
recommendation, the Parties must provide a written answer to the mediator whose contents approve or reject the recommendation within no later than 10 (ten) days after the written suggestion is received. Those who do not respond to the recommendations are considered to reject written recommendations. If the written recommendation is agreed by the Parties, no later than 3 (three) working days after the written suggestion is agreed the mediator must have finished assisting the parties in making a Joint Agreement to then be registered with the Industrial Relations Court at the District Court in the territory of the parties entering into the Agreement Together to obtain a proof of registration deed.

3) Settlement through Conciliation

That is carried out by the conciliator registered at the office of the agency responsible for the Regency / City manpower, which is carried out by conducting research on the seat of the case and holding a mediation session. In carrying out their duties, the conciliator may summon witnesses or expert witnesses to attend the mediation hearing to request and hear their statements. ${ }^{32}$ In the event that no agreement is reached, the conciliator shall issue a written recommendation within not later than 10 (ten) working days from the first mediation session. Then to the recommendation, the Parties must provide a written answer to the conciliator whose contents approve or reject the recommendation within no later than 10 (ten) days after the written recommendation is received. Those who do not respond to the recommendations are considered to reject written recommendations.

4) Settlement through Arbitration

That is done on the basis of the agreement of the parties to the dispute by the Arbitrator that has been established by the Minister. The agreement is stated in writing in an arbitration agreement made in 3 (three) copies and each party gets 1 (one) who has the same legal force. The Parties are entitled to choose one arbitrator (the single arbitrator) or several arbitrators (assemblies) in an odd number of as many as 3 (three) people from the list of arbitrators determined by the Minister. Arbitrators are required to settle industrial relations disputes within no later than 30 (thirty) working days from the signing of the appointment agreement letter. Arbitration decisions have the force of law that binds the parties to the dispute and is a final and permanent decision which is then registered at the Industrial Relations Court at the District Court in the area of the arbitrator to determine the decision. 
In the case of industrial relations disputes settlement through mediation or conciliation channels that do not meet with a resolution, then with the recommendation of the mediator or conciliator, the parties can file a lawsuit with the Industrial Relations Court at the District Court whose jurisdiction covers the place where the workers/laborers work. Where in the context of a conflict of interest, the Industrial Relations Court has the duty and authority to examine and decide on industrial relations disputes at the first and last level, ${ }^{33}$ so that the Decision issued by the Industrial Relations Court against a dispute of interest is a final and permanent decision.

\section{Conclusions}

Based on the discussion that has been presented previously, from this legal research can be concluded: First, after the enactment of Law Number 24 Year 2011 concerning BPJS there are fundamental amendments, especially those felt by employers. The amendment is in the case of health insurance provided to its employees, after the enactment of the BPJS Law, the Employer is obliged to register himself and all of his Workers in the BPJS for Health membership as implementing social security in the health sector as mandated by the National Social Security Act which was previously organized by PT Askes (Persero). Second, the mandatory membership of the BPJS for Health for all Employers raises legal implications which between the Employer and the Worker an autonomous law has been applied as an agreement on the terms of work in the form of a Collective Labor Agreement which has stipulated the pattern of health care security coverage using Private Medical Insurance since before the enactment of the BPJS Law. In this case, the Employer shall continue to implement the contents of the Collective Labor Agreement, while on the other hand, the BPJS Law instructs the implementation of health security using the BPJS for Health which then impacts a double coverage of Workers' health care security which impacts on additional financial burden to be borne by the Employer. This double health care security coverage situation is then vulnerable to bring up a conflict of interests between the Employer and the Workers which can lead to the emergence of Industrial Relations Disputes in the form of Interest Disputes. Whereas in the context of legal agreement in relation to CLA as the basis for the application of Private Health Insurance for Workers, referring to Article 1338 paragraph (2) of the Civil Code, the Agreement can be amended on the basis of good faith or for reasons determined by the Law. In this case, the enactment of BPJS Law requiring the Employer to include its Workers in the BPJS for Health membership is qualified as a public law that is compelling in nature

\footnotetext{
${ }^{33}$ Adriaan Bedner "Indonesian Legal Scholarship and Jurisprudence as an Obstacle For Transplanting Legal Institutions." Hague Journal on the Rule of Law 5, no. 2 (2013): 264.
} 
(dwingendRecht) so that it can override the provisions in the CLA on workers'health insurance, so that the BPJS Law can be used as a reason for public law to be forced (dwingendRecht) so that it can override the provisions in the CLA on workers' health insurance so that the BPJS Law can be used as a reason to amend CLA. Third, disagreements between Employers and Workers that lead to Industrial Relations Disputes which in this case are qualified as Interest Dispute that can be resolved through the mechanism determined in the Industrial Relations Dispute Settlement Law. The mechanisms that must be pursued include settlement through Bipartite, settlement through Mediation, settlement through Conciliation, settlement through Arbitration, to settlement through filing a lawsuit to the Industrial Relations Court at the District Court whose jurisdiction covers the place where the workers work.

\section{Book}

\section{BIBLIOGRAPHY}

Asshiddiqie, Jimly. Komentar tentang Konstitusi 1945 Republik Indonesia, Cetakan Pertama. Jakarta: Sinar Grafika, 2010.

Djumhana, Muhammad. Hukum Perbankan di Indonesia. Bandung: PT Citra Aditya Bakti, 2000.

Subekti, R. Hukum Perjanjian. Cetakan ke-22. Jakarta: PT Intermasa, 2008.

\section{Journal Article}

Afrilia, Veny, Suwandi Sumartias, and Lukiati Komala Erdinaya. "Transformasi PT Askes (PERSERO) Menjadi Badan Penyelenggara Jaminan Sosial Kesehatan." Jurnal Kajian Komunikasi 5, no. 2 (2017): 180-189. https://doi.org/10.24198/ikk.v5i2.8481

Bedner, Adriaan. "Indonesian legal scholarship and jurisprudence as an obstacle for transplanting legal institutions." Hague Journal on the Rule of Law 5, no. 2 (2013): 253-273. https://doi.org/10.1017/S1876404512001145

Chopra, Surabhi. "Legislating Safety Nets: Comparing Recent Social Protection Laws in Asia." Indiana Journal of Global Legal Studies 22, no. 2 (2015): 573-629.

Darma, Susilo Andi. "Kedudukan Hubungan Kerja; Berdasarkan Sudut Pandang Ilmu Kaidah Hukum Ketenagakerjaan dan Sifat Hukum Publik dan Privat." Mimbar Hukum-Fakultas Hukum Universitas Gadjah Mada 29, no. 2 (2017): 221-234. https://doi.org/10.22146/imh.25047

Hartati, Widya, "Kajian Yuridis Perubahan PT. Askes (PERSERO) Menjadi Badan Penyelenggara Jaminan Sosial (BPJS) Kesehatan." Jurnal IUS Kajian Hukum dan Keadilan $3, \quad$ no. 3 (2015): http://dx.doi.org/10.12345/ius.v3i9.265

Kesmawan, Andri Putra, and Dyah Mutiarin. "Implementasi Kebijakan Badan Penyelenggara Jaminan Sosial (BPJS) Kesehatan di Kabupaten Bantul Daerah Istimewa Yogyakarta." Journal of Governance and 
Dewa Nyoman Rai Asmara Putra,

Kadek Agus Sudiarawan and Ari Mahartha

Public Policy 1, no. 3 (2016): 505-547. http:/ /dx.doi.org/10.18196/jgpp.2014.0017

Li, Tania Murray. "The Price of Un/Freedom: Indonesia's Colonial and Contemporary Plantation Labor Regimes." Comparative Studies in Society and History 59, no. 2 (2017): 245-276. https://doi.org/10.1017/S0010417517000044

Petroski, Karen. "Legal Fictions and the Limits of Legal Language." International Journal of Law in Context 9, no. 4 (2013): 485-505. https://doi.org/10.1017/S1744552313000268

Pradima, Akbar. "Alternatif Penyelesaian Perselisihan Hubungan Industrial di Luar Pengadilan." DiH: Jurnal Ilmu Hukum 9, no. 17 (2013):1-18. https://doi.org/10.30996/dih.v9i17.251

Priyono, Ery Agus. "Peranan Asas Itikad Baik Dalam Kontrak Baku (Upaya Menjaga Keseimbangan bagi Para Pihak)." Diponegoro Private Law Review 1, no. 1 (2017): 13-22.

Remen, Omon, and Endeh Suhartini. "Dispute Settlement Of Industrial Relation of PT. Haengnam Sejahtera Indonesia in The Mediation Step of Dinas Tenaga Kerja of Kabupaten Bogor." De'rechtsstaat 4, no. 1 (2018): 63-79. http://dx.doi.org/10.30997/jhd.v4i1.1240

Setiyono, Budi, and Ian Chalmers. "Labour protection policy in a Third World Economy: The case of Indonesia." Development and Society 47, no. 1 (2018): 139-158. https://doi.org/10.21588/dns/2018.47.1.006

Shihab, Ahmad Nizar. "Hadirnya Negara Di Tengah Rakyatnya Pasca Lahirnya Undang-Undang Nomor 24 Tahun 2011 Tentang Badan Penyelenggara Jaminan Sosial (The Presence Of The State Among People After The Declaration Of Law Number 24 Year 2011 Concerning Social Security Administering Agency)." Jurnal Legislasi Indonesia 9, no. 2 (2018): 175-190.

Simarmata, Jorawati. "Urgensi Bantuan Hukum Relawan Pendamping, Pekerja Sosial dan Serikat Buruh setelah Putusan MA No 22 P/HUM/2018." Jurnal Hukum \& Pembangunan 48, no. 4 (2018): 670698. http://dx.doi.org/10.21143/jhp.vol48.no4.1798

Situmorang, Ruben. "Tinjauan Yuridis Tentang Perjanjian Kerja Bersama Ditinjau Dari Undang-Undang Nomor 13 Tahun 2003 Tentang Ketenagakerjaan." Lex Privatum 1, no. 1 (2013):115-122.

Sonata, Depri Liber. "Metode Penelitian Hukum Normatif dan Empiris: Karakteristik Khas dari Metode Meneliti Hukum." Fiat Justisia Jurnal Ilmu Hukum 8, no. 1 (2014): 15-35.

Suprianto, Arip, and Dyah Mutiarin. "Evaluasi Pelaksanaan Jaminan Kesehatan Nasional." Journal of Governance and Public Policy 4, no. 1 (2017): 71-107. https://doi.org/10.18196/jgpp.4172

Ujang, Charda S. Model Penyelesaian Perselisihan Hubungan Industrial dalam UU Ketenagakerjaan setelah Undang-Undang Nomor 2 Tahun 2004 Diundangkan. Wawasan Yuridika 1, no. 1 (2017): 1-23.

Umbas, Refly R. "Aspek Hukum dalam Perjanjian Kerja Bersama (PKB) antara Karyawan dengan Perusahaan." Lex Privatum 2, no. 3 (2014): 167-179.

Warnecke, Tonia, and Alex De Ruyter. "The enforcement of decent work in India and Indonesia: Developing sustainable institutions." Journal of 
Economic Issues 46, no. 2 (2012): 393-402. https: / /doi.org/10.2753/JEI0021-3624460214

Wisudawan, I. G. A. "The Good Faith Principle of the Parties in the Credit Agreement as an Effort to Minimize the Non Performing Loans at Koperasi Financial Institutions". Ganeswara 7 no. 2 (2013).

Yetniwati Yetniwati, Hartati Hartati, and Meriyani Meriyani. "Reformasi Hukum Penyelesaian Perselisihan Hubungan Industrial Secara Mediasi." Jurnal Dinamika Hukum 14, no. 2 (2014): 250-261.

\section{Laws and Regulations}

Constitution of the Republic of Indonesia Year 1945.

Law of the Republic of Indonesia Number 13 Year 2003 concerning Manpower, State Gazette Number 39, Supplementary State Gazette Number4279.

Law of the Republic of Indonesia Number 2 Year 2004 concerning Industrial Relations Dispute Settlement, State Gazette Number6,Supplementary State Gazette Number 4356.

Law of the Republic of Indonesia Number 40 Year 2004 concerning National Social Security System, State Gazette Number150, Supplementary State Gazette Number 4456.

Law of the Republic of Indonesia Number 24 Year 2011 concerningSocial Security Organizing Body, State Gazette Number 116, Supplementary State Gazette Number 5256.

Civil Code of Indonesia [Kitab Undang-Undang Hukum Perdata Indonesia].

Government Regulation of the Republic of Indonesia Number 86 Year 2013 concerning Procedures for Imposing Administrative Sanctions to Employers other than State Administrators and Everyone, other than Employers, Workers, and Recipients of Contribution Assistance in Providing Social Security, State Gazette Number 238, Supplementary State Gazette Number 5481.

\section{Case Law}

Constitutional Court Judgment Number 138/PUU-XII/2014, dated 7 December 2015.

Constitutional Court Judgment Number 7/PUU-XVII/2019, dated 11 February 2019. 